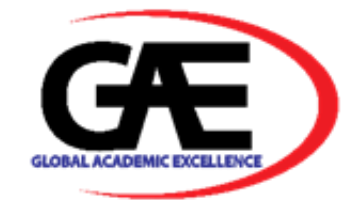

\title{
HUMANITARIAN ASSISTENCE FOR OTHER COUNTRIES WHICH AFFECTED BY DISASTER AS IMPLEMENTATION OF CONSTITUTIONAL MANDATE
}

\author{
Boby Sigit Adipradono ${ }^{1}$ \\ 1 Faculty of Law, Jayabaya University, Jakarta, Indonesia \\ Email: boby.adipradono@gmail.com
}

\section{Article Info:}

\section{Article history:}

Received date: 01.08 .2020

Revised date: 15.08 .2020

Accepted date: 10.01.2021

Published date: 05.03.2021

To cite this document:

Adipradono, B. S. (2021). Humanitarian Assistance for Other Countries which Affected by Disaster as Implementation of Constitutional Mandate. International Journal of Law, Government and Communication, 6 (22), 56-65.

DOI: 10.35631/IJLGC.622005.

This work is licensed under CC BY 4.0

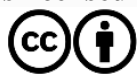

\begin{abstract}
:
The basic principles of the implementation of Indonesian foreign policy have been stated in the opening paragraph of the first paragraph of the 1945 Constitution, "that actual independence is the right of all nations. And therefore, colonization of the world must be abolished, because it is not in accordance with humanity and justice. The establishment of this country is to "participate in carrying out world order based on freedom, eternal peace, and social justice". The Indonesian people in carrying out the constitutional mandate is to help other countries affected by the disaster. The assistance is given to other countries without any regulations which are the basis for the government to pay for the assistance. The provision of humanitarian assistance to other countries by the Indonesian government has created a dilemma among officials who have the authority to issue the budget. On the one hand, the President's order must be implemented, on the other side spending the budget for humanitarian assistance to other countries affected by the disaster there are no regulations that regulate it.
\end{abstract}

Keywords:

Disaster, Humanity, Free Active Principle

\section{Introduction}

Disasters can occur because of natural events or as a result of human actions (Maarif, 2013). The Government of Indonesia has recorded several times provided humanitarian assistance, especially to countries affected by the disaster. In 2015, Indonesia had twice provided assistance to countries affected by the disaster, namely the country of Vanuatu which was hit 


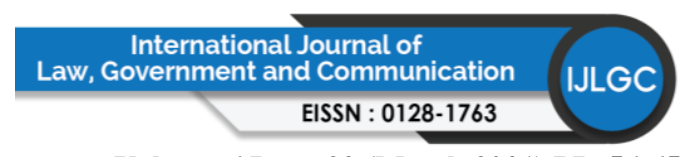

Volume 6 Issue 22 (March 2021) PP. 56-65

DOI 10.35631/IJLGC.622005

by a cyclone disaster with a total aid of 2 million US dollars, and to the country of Nepal which was hit by a massive earthquake of 1 million US dollars. One year ago, in 2016 the Indonesian Government also sent humanitarian aid to the Fiji country hit by the typhoon Winston. Humanitarian assistance is not only in the form of goods, but also deployed personnel, who have special skills needed at the affected location (BNPB Indonesia data).

The basic principles of the implementation of Indonesia's foreign policy have been stated in the opening of the 1945 paragraph of the first paragraph, Indonesia believes "that in fact independence is the right of all nations. And therefore, the occupation of the world must be abolished, because it is not in accordance with the fairy of humanity and fairy of justice ". Indonesia also believes, the formation of this country is to "participate in carrying out world order based on independence, eternal peace and social justice" (Indonesia's Constitutional Text of 1945). These two principles turned out to be the driving force of Indonesia's foreign policy which was sparked in a free and active foreign policy. Free means that the Indonesian nation has the right to determine its attitude to face existing problems without taking sides with the bloc of forces or military alliance in the world. Active means that Indonesia is always fighting for "independence, lasting peace and social justice" in the world. The free active principle of is a source of foreign policy implemented by Indonesia. Indonesian leaders apply this principle in accordance with the situation of the existing international system. The active principle mandated in the 1945 Constitution which means fighting for independence, lasting peace and social justice, has played an important role in the Indonesian government's steps so far. One of the steps of the Indonesian people in carrying out the mandate of the 1945 Constitution, is to help other countries affected by disasters that cause humanitarian problems.

The principle of Justice, certainty and usefulness is the purpose of the enactment of a regulation. All three principles must be treated in a balanced and harmonious manner with each other. The principles of justice, certainty and usefulness in Law number 24 of 2007 concerning disaster management have been arranged in such a way as to form a harmonious and balanced regulation. In the case of the delivery of humanitarian assistance by the Indonesian government to other countries which affected by the disaster, the three principles, certainty, justice, and usefulness are not carried out in harmony and balance. The principle of usefulness is more inclined to the front compared to the principle of justice and legal certainty. In the case of sending humanitarian assistance to the affected country by disaster, there are no regulations use of emergency funds to carry out these activities. The government, in this case the Indonesian president, puts forward the free active principle and usefulness principles related to providing humanitarian assistance to the affected countries by disaster.

As stated by Peter Mahmud Marzuki, the scope of problems include three things: the existence of different or contradictory interpretations of the text of the regulation due to the unclear regulation itself; the occurrence of a legal vacuum; and there are different interpretations of facts (Marzuki, 2005). So, the current problem is the legal vacuum regarding the use of emergency funds to help other countries which affected by disasters. To solve this problem, research is needed regarding how to resolve cases of sending humanitarian aid to other countries affected by disasters using emergency funds that are linked to the free active principle (conceptual approach and statute approach (Marzuki, 2008). 


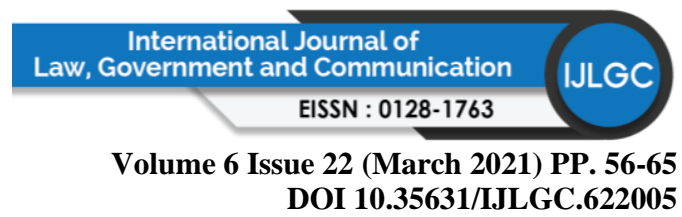

\section{Literature Review}

There are three points will be discussed in this paper : the legal certainty principle, free active principle, and the state's authority in carrying out the constitutional mandate in Indonesia.

In this paper, the analysis is limited to how legal certainty related to the policy of sending humanitarian aid to other countries which affected by disasters that has not been regulated in legislation is related to the free active principle.

This research uses normative juridical methods, with the following approaches. First, the conceptual approach to knowing the law substance of the absence of regulations regarding the use of emergency funds that used for humanitarian assistance to other countries which affected by the disaster. Secondly, the statute approach to examine the use of emergency funds for humanitarian assistance to other countries which affected by the disaster that are the basis of the actions of government officials in using emergency funds for these activities.

\section{Definition of The Legal Certainty}

According to Kelsen, law is a norm system. Norms are statements that emphasize the "should" or das sollen aspects, including some rules about what should be done. Norms are deliberative human products and actions. Laws that contain general rules serve as guidelines for individuals behaving in society, both in relationships with fellow individuals and in relations with society. These rules become a limit for society in burdening or taking action against individuals. The existence of these rules and the implementation of these rules give rise to legal certainty (Wantu, 2007).

The doctrine of Law ideals (idee des Recht) revealed by Gustav Radbruch, mentions the necessity of three elements that must exist in a balanced manner, legal certainty (rechtssicherkeit), justice (gerechtighkeit) and usefulness (zweckmasigkeit) if it is associated with law enforcement (Erwin, 2011). The principle of certainty is a matter on which the law is obeyed as a reference for government officials and administrators in ensuring the role of the government as it should.

The dose of justice itself is relative. The definition of what is fair is different for each individual. It is no exaggeration if justice is something that is difficult to define, but can be felt and is an element that cannot but must not exist and is not separated from the law as a set of principles and rules that guarantee the existence of order (certainty) and order in society (Kusumaatmadja dan B. Arief Sidharta, 2000).

In classical theory, the objective of classical law is known as dogmatic normative theory. This theory states that the purpose of law is merely to create legal certainty. It is hoped that with legal certainty there will be order, peace, peace and expediency as well as a sense of justice in social life. This theory is in accordance with that proposed by G. Radbruch that something that is created must have a goal or goal. The law made also has a purpose. This goal is a value to be realized by humans. The main legal objectives are three, justice for balance, certainty for accuracy, and usefulness for happiness.

Normative legal certainty is when certain regulations are made and promulgated, because it regulates clear and logic. Clear in understanding, it does not cause doubt and is logical and is a norm system and does not cause conflict. The law is a manifestation of the orders and wishes 


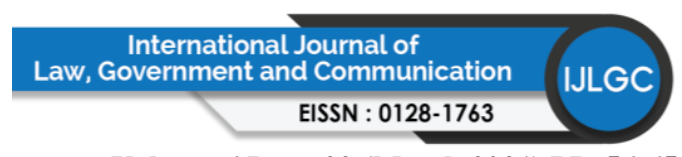

Volume 6 Issue 22 (March 2021) PP. 56-65

DOI 10.35631/LJLGC.622005

of the state carried out by the government to carry out the trust and protection of citizens, both inside and outside their territories and realize the legal objectives.

The law maintains peace and carefully weighs conflicting interests by trying to strike a balance between those interests, so that the law can achieve the goal of justice by balancing the interests protected for everyone to get their share through regulations that contain the continuity of interests. The law must determine general rules, equalization, justice requires that each case must be weighed separately (ius suum cuique tribuere) (Apeldoorn, 2009). In the ethical theory (etische theorie), achieve justice is only thing that the purpose of law. In This theory, the laws that apply to a particular nation must be based on the ethical awareness of the nation, which should produce the right views of the values of a good life (Tutik, 2006).

Certainty is a characteristic that cannot be separated from the law, especially for written legal norms. Law without certainty will lose its meaning because it can no longer be used as a code of conduct for everyone. Certainty itself is referred to as one of the objectives of the law. When viewed historically, the discussion about legal certainty is a conversation that has emerged since the idea of the separation of powers from Montesquieu. Legal certainty requires an effort to regulate law in legislation made by authorized and authoritative parties, so that the rules have a juridical aspect that can guarantee the certainty that law functions as a rule that must be obeyed. In the scope of government, all government activities are carried out using the budget from state revenues. In the case of state administrative law, every budget used in an activity must be used in accordance with established regulations as an accountability to the society.

\section{Definition of Free Active Principle}

Aristotle - the ancient Greek polymath and acknowledged founding father of political science - characterized humankind as a Zoon Politicon, is mean humans need each other, as well as the nation which is a collection of human communities. A country cannot stand alone without assistance or cooperation with other countries including Indonesia. As part of the international community, Indonesia also needs a variety of international cooperation to fulfill the needs of its country and to achieve the country's national interests. This happens because the inequality of resources owned by each country. That's relationship call named foreign politics. The Indonesian concept of foreign policy is a free active.

Authority is a matter that becomes the basic principle in every administration in a country based on the applicable laws and regulations. Sometimes in carrying out their duties and functions as public officials, government administrators are faced with problems that are not or have not been regulated in the legislation. In the concept of constitutional law and administrative law, actions outside the existing regulations or provisions can still be justified, so that legal principles or concepts in their operations continue to run dynamically, efficiently, and effectively. The concept or principle above is referred to as Discretion (discretion). Discretion has a very important role in all aspects of national and state life (Wehmeier et al, 2006).

The implementation of Indonesia's foreign policy is mandated by the fourth paragraph of the 1945 Constitution "that in fact independence is the right of all nations. And therefore, the occupation of the world must be abolished, because it is not in accordance with the fairy of humanity and fairy of justice which states that the Government of Indonesia must participate in realizing world order based on independence, lasting peace and social justice. The meaning of the mandate, the Indonesian government must participate in fighting for the liberation in the 


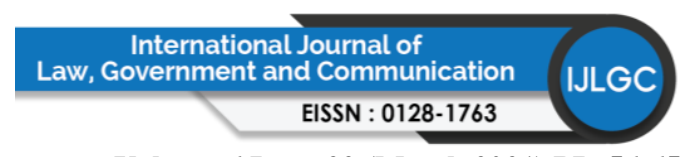

Volume 6 Issue 22 (March 2021) PP. 56-65

DOI 10.35631/IJLGC.622005

world from all forms of colonialism. Indonesia's must also actively realize the achievement of world peace in the form of active involvement in resolving conflicts in certain regions as well as the struggle for world peace.

A country's foreign policy was born when the country was declared as a sovereign state. Every sovereign country has a policy that regulates its relations with the international community, both in the form of the state and other international communities. It's a part of the foreign policy carried out by the state and is a reflection of its national interests. Indonesia as a sovereign country also runs an ever-expanding foreign policy adapted to domestic needs and changing international situations.

A country's foreign policy, which is a combination of national interests, national goals, geopolitical position or configuration and national history, is influenced by domestic (internal) and international (external) factors. In other words, foreign policy is an effort to bring together national interests, especially national development plans with developments and changes in the international environment. foreign policy of each country is continued and is a reflection of domestic politics. By taking part in the international arena, a country is expected to be able to articulate domestic interests and needs, so that domestic problems can be resolved. More importantly, foreign policy is directed at efforts to link national development strategies and policies and steps taken at the international level.

The foundation in the implementation of Indonesia's foreign policy is Pancasila which is the basis of the Indonesian state. The values contained in the Pancasila are used as a guide and a footstool in the implementation of Indonesian foreign policy. Mohammad Hatta, the first vice president Indonesia called it one of the factors that shaped Indonesia's foreign policy.

A five points are contained in Pancasila, containing basic guidelines for the implementation of an ideal life of the nation and state and covering all the joints of human life. Hatta further said that Pancasila was one of the objective factors that influenced Indonesian foreign policy. This is because Pancasila as the state philosophy binds the entire Indonesian nation, so that any group or political party in power in Indonesia cannot run a state policy that deviates from Pancasila.

The purpose of a free active foreign policy is to serve the national goals of the Indonesian people listed in the Preamble to the 1945 Constitution the fourth paragraph stating: "Protect all Indonesians and all of Indonesia's blood and to promote public welfare, develop the life of the nation, and participate in carrying out world order. based on eternal peace and social justice ... "Then in order that the principle of free active can be operationalized in Indonesian foreign policy, every period of government establishes the operational foundation of Indonesia's foreign policy which is constantly changing according to national interests."

Officially, Indonesia's foreign policy only took its form when the first Vice President of Indonesia Mohammad Hatta gave his statement to BP KNIP (Central Indonesian National Committee for Workers) regarding Indonesia's political position in September 1948, at that time Hatta said that:

"..... but it is imperative that we Indonesians who fight for the independence of our nation must choose between pro-Russian or pro-American. Are there no other positions we must 


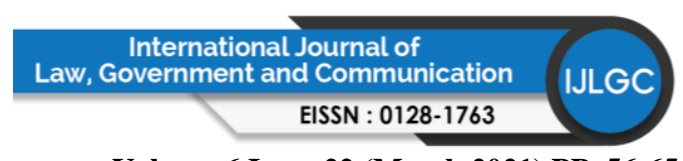

Volume 6 Issue 22 (March 2021) PP. 56-65

DOI 10.35631/IJLGC.622005

take in pursuing our ideals? The government is of the opinion that the position we must take is so that we do not become objects in the international political struggle, but we must be subjects who have the right to determine our own attitude, have the right to fight for our own goals, namely Indonesia as a whole independent."

From the Mohammad Hatta's statement, it was clear that Indonesia wanted to not side with one of the existing blocks at that time. Even aspiring to create lasting world peace or at least alleviate the existing Cold War by being friendly with all countries both in the West and East Bloc, because only in this way can the ideals of the struggle for independence of the nation and the Indonesian state be achieved.

Hatta's thought Indonesia must have foreign policy to reduce international politics at the time so that it would be free from intervention from countries that dominated the cold war. Economic conditions that are relatively weak but have a great patriot spirit make the Indonesian government must determine the direction of its foreign policy to build the image of Indonesia in the international community. Hatta said that Indonesia's foreign policy was "like rowing between two reefs", meaning that Indonesia's foreign policy was in a neutral position between the two major powers of the world; America and the Soviet Union. The foreign policy undertaken by Soekarno, the Indonesia's first president, tended to approach Chinese socialist groups. Actually this policy was not directly related to the ideological conflict that was taking place at the time, but was more colored by the spirit of opposing colonialism that was still ongoing in several Asian and African countries. Ongoing colonialism in some Asian and African countries is practiced by the US capitalist and its allies, while countries that are still under colonial rule have opposing views of socialist countries such as China.

But even though Indonesia chose not to side with one of the existing blocks, that did not mean that Indonesia intended to create a new block. Therefore, according to Hatta's, Indonesia was also not willing to hold or interfere with a third block intended to offset the two giant blocks. This attitude later became the basis of Indonesia's foreign policy which is commonly referred to as Free Active, which means that in carrying out its foreign policy, Indonesia is not only impartial but also "active" in efforts to maintain peace and ease the existing conflict between the two blocs with how to "free" make friendships with all countries on the basis of mutual respect.

Since Mohammad Hatta delivered his speech entitled "Riding Between Two Reefs" in front of the KNIP BP Summit in September 1948, Indonesia has embraced a free-flowing foreign policy that is understood to be Indonesia's basic attitude of refusal to join any of the Blocks of superpower countries, against development foreign military bases in the country, and refuses to be involved in the defense of major countries. However, Indonesia still tries to be actively involved in every effort to ease tensions in the international world (Opening of the 1945 Constitution).

The free active Indonesian foreign policy can be interpreted as policies and actions taken or deliberately not taken by the Government in relation to foreign countries or international and regional organizations that are directed to the achievement of state goals. This active free foreign policy then became the principle in the implementation of Indonesia's foreign policy during the next Government periods. Of course, the implementation of a free active foreign 


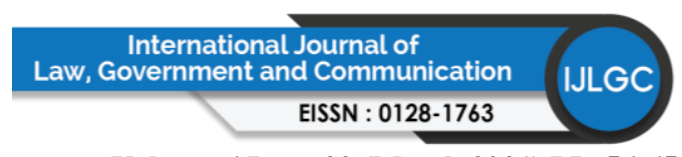

Volume 6 Issue 22 (March 2021) PP. 56-65

DOI 10.35631/LJLGC.622005

policy was also adjusted to domestic interests and the constellation of international politics at the time.

Foreign policy is a response to the international situation although it is always based on domestic needs. The principle of free substantially implies the freedom of our ideas and movements to independently decide on foreign policy without pressure and foreign intervention. The active principle contains the meaning of the fire of the spirit of humanism and universalism to participate in creating world order based on freedom, eternal peace and social justice.

The outbreak of World War II has given rise to bipolarization in the world so that the two blocs, namely the Western bloc and the Eastern bloc, are formed where the Western bloc is a stronghold that is in line with the United States (US) and the Eastern bloc is a Soviet-like stronghold. The two superpowers fought a cold war. As a result of the cold war came deconsolization in various parts of the world, namely the abolition of colonies so that several countries declared their independence.

Since the mid-1950s, Indonesia has initiated and adopted of very important and monumental foreign policies, such as the Asian-African Conference (KAA) in Bandung in 1955. Indonesia's participation in shaping the solidarity of newly independent nations in the Non-Aligned Movement forum. This forum is a reflection of the division of the world into two major powers; the Western bloc (US) and the Eastern bloc (Soviet Union), as well as the concept of a free active foreign policy trying to help the nations of the world that have not been separated from the shackles of colonialism. Indonesia's success in gaining international recognition through this negotiating table has become the starting point for Indonesia's diplomatic struggle to achieve its interests.

The Indonesian government's foreign policy was influenced by developments in international politics which at that time entered the beginning of the Cold War in 1960. With the condition of Indonesia at that time, as a newly established country, then looking for positions in the international community and building a profile of themselves in the international world.

The free active principle of is clearly contained in the preamble to the 1945 Constitution which contains parts :

The fact that independence is the right of all nations and therefore the occupation of the world must be abolished because it does not conform to humanitarian and justice.

Then rather than that, to form an Indonesian state government that protects all Indonesian people and all Indonesian blood spills and to advance public welfare, educate the nation's life and participate in carrying out world order based on independence, eternal peace and social justice, a law was drafted. the constitution of the Republic of Indonesia.

That quotation clearly demands that Indonesia oppose all forms of colonialism and help promote world peace. In universal language, it can be said that Indonesia adheres to the principles of anti-colonialism and anti-imperialism. The free active principle adopted by Indonesia indicates Indonesia's reluctance to commit itself to one of the blocks. This aspect is universally known as non-alignment policy. The principle of non-alignment then animates the foreign policy of several Asian and African countries. It was this awareness that drove the Asian-African Conference (KAA) in 1955 in Bandung. 


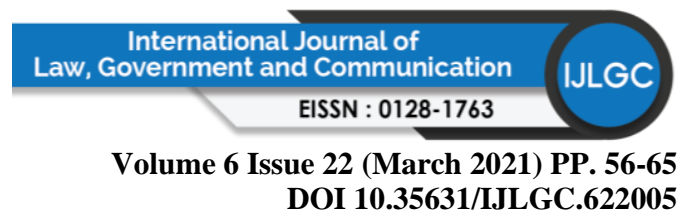

The concept of a free active Indonesian foreign policy itself is an illustration and effort of Indonesia to help realize world peace. This free active principle foreign policy will not fade by time. However, it will continue to contribute and always be part of the solution to the problems of nations by promoting a win-win solution approach.

The principle of active and free foreign policy has become the sole principle of the Indonesian nation after independence. Free in the sense of being free to determine attitudes to international problems and free from the influence of the eastern bloc with its communist ideology and the western bloc with its liberal understanding. While the meaning of the word active is always active in fostering international peace. In realizing an active principle in the international world, the Indonesian government also actively contributes to providing humanitarian assistance to countries which affected by the disaster. Providing assistance to other countries in addition to maintaining the stability of international relations, is also expected to be a soft diplomacy for certain countries that are believed by the Government of Indonesia to provide political benefits for the country's stability.

The existence of the law aims to provide security, order and ensure the welfare of the people obtained from the State as a social scope. Rule of law in addition to human interests against the dangers that threaten it, also regulates the relationship between humans (Wehmeier et al, 2006). It is a necessity that every society will always develop over time. The development of a society that cannot be withstand has an impact on the legal aspects which are always demanded to follow the development of the community itself. If the law is late or does not follow the increasingly rapid development of society, it is certain that legal chaos will occur within the community itself.

Research on Indonesia's foreign policy is often done. Some recent research on Indonesian foreign policy, for example, was carried out by Syamsul Hadi (Hadi, 2012) on Indonesia's response to the rise of China which had a security and economic impact. In the context of security, the presence of China makes countries outside the region such as the US to play a greater role as a counterweight. Then Evan A. Laksman's research examines the profile of Indonesia's foreign policy based on geographical position and population (Laksamana, 2011). According to Laksmana, manifesting Indonesia's foreign policy and global profile is always based on the use of normative and moral values. The use of norms has been carried out by Indonesia in various international forums such as ASEAN. Then, the democratization that took place since 1998 made Indonesia's reputation better in the international world which was then used as a source of soft power. In particular, Laksmana underlined Indonesia's geographical position and large population which could be a threat to Indonesia because the government was unable to meet the minimum requirements in defense. Historical research also carried out by Paige Johnson Tan in Navigating a Turbulent Ocean: Indonesia >Worldview and Foreign Policy in the 2007 Asian Perspectives explores the definition, origin and outlook of Indonesia in international relations (Tan, 2007). Indonesia as a country with vast territory, history, culture. Strategic location and the principle of foreign policy have a role as a leader in the region.

The government of Indonesia also adheres to the reciprocity principle which is complements the free active Indonesian foreign policy. One of The free active principle is seen in humanitarian assistance for other countries which affected by disasters. The free active principle is inseparable from the reciprocity, which complement each other and benefit each 


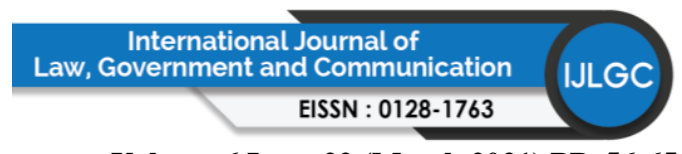

Volume 6 Issue 22 (March 2021) PP. 56-65

DOI 10.35631/IJLGC.622005

other in international community. Reciprocity is generally defined and known as the principle of interaction between individuals, communities or countries that results in positive or negative forms. In international community, reciprocity describes an environment in which countries support one another for short-term or long-term benefits through balancing rights, duties and interests. Reciprocity is very relevant when there are no legal obligations but moral or social obligations. International Law Commission (ILC) where reciprocity is defined by them as sharing specific rights between States; that is to say when one State benefits from a right then others must share the same right (Yearbook of the International Law Commission, 1976 ). The general definition of reciprocity is, 'a situation in which two people, countries,..., provide the same help or advantages to each other... ( Beatson et al (2011). As part of the international community, the government takes part in various international activities. the speaker of humanitarian assistance to the affected country by disaster is the realization of the mandate of the country's constitution to realize world order based on independence, lasting peace and social justice.

\section{Definition of State's Authority in Carrying Out The Constitutional Mandate}

From various definitions of government policies, there is a very important key word, that the policy is born of a need, of the interests of society, of the interests of the administration of the state in line with the interest's people of Indonesia's welfare. The policy is the process of interaction with the environment and other institutions in the scope of government officials.

Therefore, in order for government policies to have a strong legal foundation, solid legal certainty, then all government policies must have constitutional references or grounds for thinking. The device is in the form of the Constitution and the 1945 Constitution.

\section{Implementation of Humanitarian Assistance Policies}

The activities of sending humanitarian assistance to other affected countries by disasters have been carried out several times by the Indonesian government within the scope of social ethics in the international community. Humanitarian assistance to other affected countries by disasters is a constitutional mandate other than as an embodiment of the free active principle adherence to the government. The use of government budget in sending humanitarian aid activities to other countries which affected by disasters that do not use the basis of regulations should be considered unfavorable. Related to this, the government uses its authority in terms of using the budget for humanitarian assistance by ignoring the existing rules for the achievement of the constitutional mandate. The government should first make regulations regarding the use of the budget for humanitarian assistance before carrying out these activities so that legal certainty is achieved.

\section{Reference}

Apeldoorn, L.J. V. (2009) Inleiding tot de Studie van het Nederlands Recht. Terjemahan Oetarid Sadino. (2009). Pengantar Ilmu Hukum. Jakarta: PT. Pradnya Paramita.

Beatson, et al, (2011) Administrative Law: Text and Materials, Oxford University Press, UK. BNPB Indonesia data.

Erwin, M. (2011). Filsafat Hukum. Refleksi Kritis Terhadap Hukum. PT. RajaGrafindo Persada.

Hadi, S. (2012). Indonesia, ASEAN, and the Rise of China: Indonesia in the Midst of East Asia's Dynamics in the Post-Global Crisis World. International Journal of China Studies, (3)2, 151-166.

Indonesia's Constitutional Text of 1945. 
Volume 6 Issue 22 (March 2021) PP. 56-65 DOI 10.35631/IJLGC.622005

Kusumaatmadja, M. dan Sidharta, B. A. (2000) Pengantar Ilmu Hukum, Suatu Pengenalan Pertama Ruang Lingkup Berlakunya Ilmu Hukum. Bandung: Alumni.

Laksmana, E. A. (2011). Indonesia's Rising Regional and Global Profile: Does Size Really Matter?. Contemporary Southeast Asia (33)2, 157-182.

Maarif, Syamsul.(2013). Harmonization of Law in Disaster Management. Military Law Journal, (1)7.

Marzuki, P. M. (2005) Penelitian Hukum. Kencana.

Marzuki, P. M. (2008) Pengantar Ilmu Hukum. Kencana.

Tan, P. J. (2007). Navigating A Turbulent Ocean: Indonesia's Worldview and Foreign Policy. Asian Perspectives.

Tutik, T. T. (2006). Pengantar Ilmu Hukum. Prestasi Pustaka.

Wantu, F. M. (2007) Antinomi dalam penegakan hukum oleh hakim. Jurnal Berkala Mimbar Hukum (19)3.

Wehmeier, S. et al. (eds.). (2006), Oxford Advanced Learner's Dictionary.

Yearbook of the International Law Commission, 1976, Vol. II, Part Two, Report of the Commission to the General Assembly on the work of its twenty-eighth session. 